\title{
ESTABLISHMENT OF NEOCHETINA SPP.: THEIR PATTERN OF LOCAL DISPERSAL AND AGE STRUCTURE AT THE RELEASE SITE
}

\author{
KASNO, ASMARINA S.R. PUTRI, SRI WIDAYANTI AND SUNJAYA
}

SEAMEO BIOTROP, P.O. Box 116, Bogor 16001, Indonesia

\begin{abstract}
Study on the distribution pattern and age structure ofNeochetina spp. (Coleoptera: Curculionidae) at the release site was conducted to know a) the distribution pattern of the weevil, b) its establishment status, c) its survival rate in the field, and d) relationship between the attack of the weevil and the fungus, Altemaria eichhorniae Nag Rag \& Ponappa (Hyphomycetes), in causing damage to water hyacinth. This study was conducted at Situ Bagendit lake, Garut, West Java.

A release and recapture method was employed to study the mode and rate of dispersal of the weevils under field conditions. Regular sample collection at two-month interval was done to evaluate the pattern of distribution and to assess the age structure under field condition. Another two months regular observation was done to assess damage severity due to adult weevils and the fungus, A. eichhorniae, on water hyacinth.

Results showed, that the weevils seem to disperse actively to all directions following the presence of water hyacinth. The data also showed that the dispersal rate of the weevils was about a few meters a week. Under field conditions at Situ Bagendit lake, the weevils were about evenly distributed throughout water hyacinth mass. The density of the weevils fluctuated from time to time, but the trend slightly increased. The survival rate of the weevils at Situ Bagendit lake was estimated not more than 5\%. It was suspected that various limiting factors such as various predators have caused the low population increase under field conditions. The population increase through time confirmed that the weevils have established at Situ Bagendit lake. Field data showed that there were no interaction between the damage severity of the weed caused by both weevils and the fungus.
\end{abstract}

\section{INTRODUCTION}

Water hyacinth, Eichhornia crassipes (Mart.) Solms - Laubach (Pontederiaceae), is one of the most important aquatic weed and causes various serious problems in Indonesian water bodies as well as in some other tropical and subtropical regions of Southeast Asia. Various efforts to control water hyacinth have been attempted including the use of biotic agents. BIOTROP initiated researches on biological control of water hyacinth by conducting a seminar on Aquatic Weed Management in 1974 followed by introducing water hyacinth weevil, Neochetina eichhorniae Warner (Coleoptera : Curculionidae) from Florida in 1975.

Aside from N. eichhorniae, BIOTROP in cooperation with ACIAR and CSIRO has also imported in 1994 another weevil species, i.e., Neochetina bruchi Hustache (Coleoptera : Curculionidae) for the same purpose. Both water hyacinth weevils have also been tested and released in the fields of many countries including Indonesia where this weed has been introduced to those countries (Julien and Griffith 1998; Barley 1990). 
Research activities on biological control of water hyacinth have been conducted in many countries, generally using insects, fungi and fish as biological control agents (Harley 1990). The significant role of Neochetina spp. as biocontrol agent of water hyacinth has been reported from different countries such as Queensland (Wright 1979; Room 1986), Sudan (Bashir 1984), Bangalore (Jayanth 1988) and Louisiania (Goyer and Stark 1984).

Other studies showed that better control of water hyacinth may be achieved by the integrated use of water hyacinth weevils with other biocontrol agents such as fungi (Saraswati 1980; Charudattan 1986; Galbraith 1987; Gaunter and Mohamed 1992).

The release of $N$. eichhorniae has been conducted at some release sites in Indonesia but after some time only partial control of water hyacinth has been achieved. For experimental purposes $N$. bruchi has been released at Situ Bagendit lake in August 1996 and October 1996 consisting of 100 and 125 pairs, respectively. Further releases in the same site were done in September 1998, December 1998, January 1999, August 1999, December 1999 consisting of 265, 600, 262, 307, 700 adults ofN. bruchi and N. eichhorniae. Another biological control agent is a fungus, Alternaria eichhorniae Nag Raj \& Ponappa (Hyphomycetes), found in the lake, but its role has never been recorded. The role of the fungi to control water hyacinth at experimental scale combined with $N$. bruchi resulted in a more serious damage.

The aims of the study were : to study the distribution pattern of Neochetina spp. at the release site and the composition amongst the developmental stages of the weevils; to evaluate the establishment of Neochetina spp. at the release site; and to study the relationship between water hyacinth damage severity due to Neochetina spp. and $A$. eichhorniae at the release site.

\section{MATERIALS AND METHODS}

\section{Mode and rate of dispersal and distribution of the water hyacinth weevils under open field}

The release of the weevils was done at Situ Bagendit lake, Garut regency. The water body of the lake was originally 124 ha, but when the research was carried out the estimated water body varied from 30 ha (in dry season) to 50 ha (in rainy season). There were few blocks of water hyacinth mats. The biggest water hyacinth mat was about 0.5 ha on which the experiment was carried out. The aim of this experiment was to evaluate the mode, dispersal rate and distribution pattern of the weevils at the release site.

A total of 307 adults of Neochetina spp. marked with spotted white color on their elytra consisting of 174 males and 133 females were released in the center of Situ Bagendit lake as the first release. Three months later, the second release consisted of 350 marked adult males and 350 marked adult females. Fortnight observation was conducted using transect method. From the release point, transects 
were drawn to the four cardinal directions, and hence the presence of adult weevils marked with spotted white color was observed. The parameters observed were distance from the release point and the number of adults at $1 \mathrm{~m}^{2}$ area.

Age structure of water hyacinth weevils in the field

The structure of developmental stages or the age structure of Neochetina spp. was determined at Situ Bagendit lake. The aim of this experiment was to assess the age structure of those weevils at the release site.

Ten units of water hyacinth samples measuring 50 x $50 \mathrm{~cm}$ each were collected for further examination on the number of eggs, larvae, pupae and adults. Each sample was taken from the systematic points of diagonal imaginary lines crossing the compact floating water hyacinth mat. Regular observations at monthly interval were conducted starting from June 1999 until the end of January 2000.

The experiment was also conducted to prove the hypotheses that there were predaceous fish affecting the survival trend of the weevils under field conditions of the lake. Floating screen cages, measuring 125 x 175 x $75 \mathrm{~cm}$ each, were used as unit plot of the experiment. Each cage contained water hyacinth plants covering about $0.25 \%$ of the water surface. Each cage was provided with 2 pairs of adult weevils, 23 eggs and 25 larvae. There were 10 cages split into two groups. Group 1 was equipped with screen net on the root areas under water surface in such a way that the net did not affect the root development, while Group II was not. The plots were arranged in a randomized layout into two rows. The space between the rows was about $1 \mathrm{~m}$ and space between cages in each row was about $0.5 \mathrm{~m}$. Observations were done on the number of adult weevils and pupae in each cage on the $60^{*}$ and $120^{\text {th }}$ day after setting.

Relationship between the attacks of water hyacinth weevils and leaf blight

Using the same collected samples given above, the damage severity of each sample unit was assessed by estimating the area of the leaves attacked by the weevils and the fungus. The collected data were then analyzed on its correlation.

\section{RESULTS ANDDISCUSSION}

Mode and rate of dispersal and distribution of the water hyacinth weevils under open field condition

When an exotic biotic control agent of a weed is released in an open field, they are free to express their true behavior. The release using adult weevils, both $N$. eichhorniae and $\mathrm{M}$ bruchi, instead of other developmental stages is due to the fact that adult weevils are the most suitable as well as practical in handling. 
If the phytophagous insects are collected from the field, and cultured under artificial condition in the laboratory, they are generally to some extent, suffering from stress. Culturing insects under such condition for a longer period may reduce their vitality, the longer the worse. How many generations of insects suffering a significant reduction in its vitality vary from species to species (Donnelly 1997). Adult weevils of either $N$. eichhorniae or TV. bruchi to be released in an open field were originated from outdoor screen cage cultures. In the outdoor screen cage, the weevils were expected to start adapting to the new environment. Such treatments were intended to provide opportunity to recover the loss of vitality, because good quality is more important than quantity of a weed biotic control agent (Julien et al. 1999) . As soon as the weevils were released in the open field, they might express whatever they like such as feeding on the preferred available host plants, breeding and spreading naturally.

It was expected that soon after the release the adult weevils would not move far away from the release point and settle far from each other. If they disperse far from each other it may reduce the opportunity to meet each other for a mating process. Data on the dispersal of released weevils collected from the experimental release site and recapture showed that the adult weevils spread through all cardinal directions (Figure $1)$.

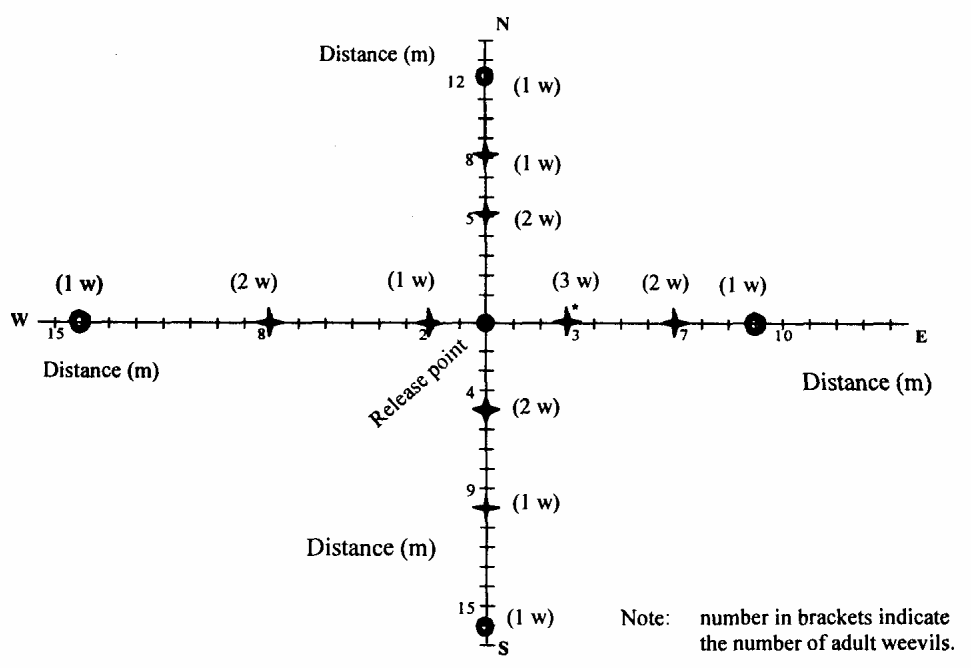

Figure 1. Distribution of adult N. eichhorniae and N. bntchi after $2\left(^{*}\right)$ and $4(\mathrm{O})$ weeks from the release time at Situ Bagendit lake 
Data from the first release of 307 marked weevils showed that two weeks after release the weevils dispersed to all cardinal directions with various distances. Data collected on the $4^{\text {th }}$ week after release showed a similar pattern but with longer distance. The longest distance on most cardinal direction almost reached the border of the water hyacinth mat within four weeks after release. Outside of the water hyacinth mat, one of the border areas was swampy but with no water hyacinth, the two other borders were grassland and agricultural land and the rest of the borders (West and North) was the open water surface of the lake. With the assumption that the rate of dispersal from the release point was about the same, if the area of water hyacinth mat was larger, it is estimated that the adult weevils would have dispersed about $15 \mathrm{~m}$ within 4 weeks. Besides, the limited size of the water hyacinth mat prevented spotting of the marked adult weevils. Therefore, the plan to conduct observation on the $6^{\text {th }}$ week was not carried out.

The release of 700 marked adult weevils showed similar results. However, some parts of the water hyacinth mat on the western and northern parts were moved away by the wind before the first and second observation, respectively. Therefore, there was no data representing weevil's distribution on western and northern parts from the release point.

Within a fortnight they were observed to move several meters away from the release point farther from the original site. It seemed that the adult weevils moved by crawling from plant to plant amongst the connected plants instead of flying. Probably they could fly to move to disconnected water hyacinth plants. The data indicated that within four weeks after release, the adult weevils spread unevenly.

The presence of young leaves which started to open from folded stage probably attracted the weevils. The young leaf is softer than the older, because the nitrogen content of young leaf is much higher than the older leaf (Center and Wright 1991). The difference in nutrient content was suspected to be one of the reasons of feeding preference. Young leaf stage was most preferred by the adults during the day.

After about two and a half years from the release of the first batch in the Situ Bagendit lake, adult feeding scars on the leaves could be found on most of water hyacinth plants growing on almost all parts of the lake. Generally, adult weevils prefer to feed on young laminas which have just started to open from closed stage. Assuming that water hyacinth suffered from adult feeding scars, the weevils have spread almost all over the water hyacinth area.

It seems that within a few weeks after the release most of the adult weevils were still confined in one area where the distance between their standing position is relatively close. With such position, it is believed that the possibility of mating is still high. Therefore, releasing water hyacinth weevils in a new environment by liberating few hundred adults of mixed sex at one site is safe.

\section{Age structure of the water hyacinth weevils in the field}

After releasing in an open field the weevils have to adapt to the local conditions as well as to encounter various limiting factors. The ability to adapt to the 
new environment may be shown by some indicators such as the presence of damage symptom as the result of feeding activity, the presence of various developmental stages, the sustainable generations, and the most important indicator is the increased population density through time.

Monthly interval sample collection was carried out to evaluate the age structure of the weevils at the rdease site. It was indicated that the weevils have spread to most water hyacinth plants in the lake.

Figure 2 shows the population trend of each developmental stage of the weevils under field conditions. A trend of increase through time was shown by adult and a slight increase was also shown later by the pupal stages.

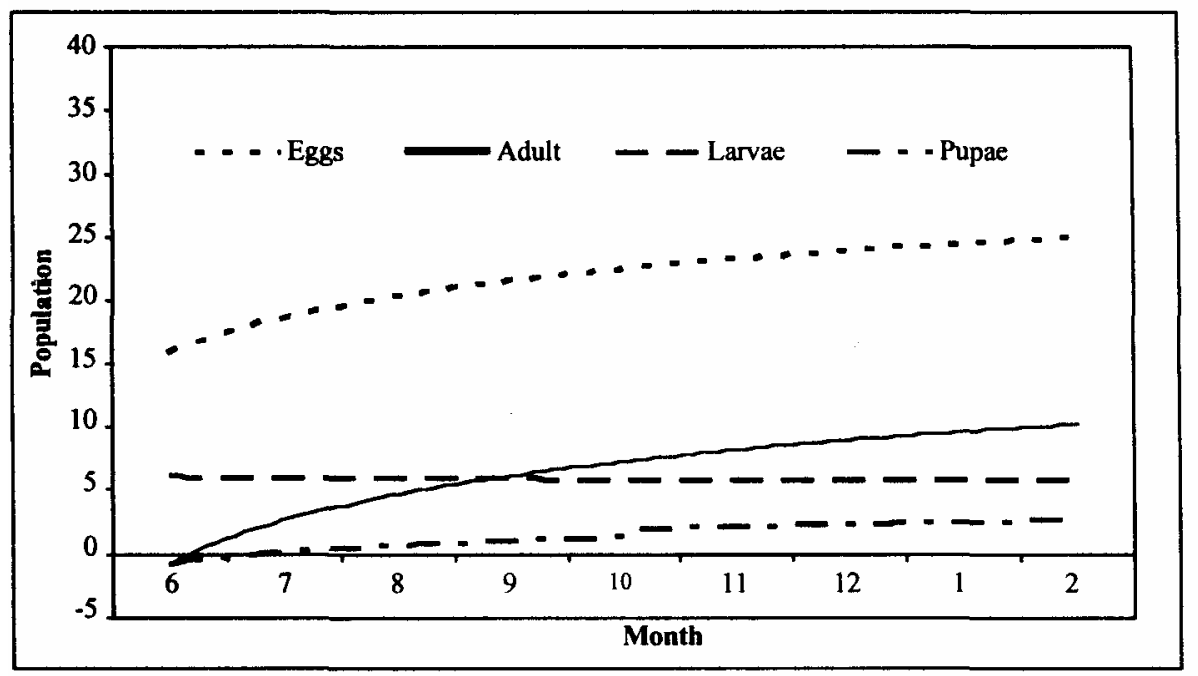

Figure 2. Population trend of each developmental stage of Neochetina spp. from June 1998-February 1999 in Situ Bagendit lake

The number of adults was mostly higher than the pupae because there was an accumulation of the survived adult of the overlapped generations as the average longevity of the adult was much longer than the average developmental period of both pupa and larva. It was questioned why the increase in the number of adults in September was not followed by the increase in the number of both eggs and larvae. The trend of the number of larvae from month to month was more or less stable which might be an indicator of the limit of carrying capacity of water hyacinth plant in the lake.

The decreasing trend from the number of eggs to larvae and pupae is shown in Figure 3. Such curve may provide information on the age structure and the survival rate of the weevils at the release site. About $5 \%$ of eggs could survive up to the 
pupal stage and less than $5 \%$ may survive up to the adult stage. This estimated survival rate was much lower than the reproductive potential determined under laboratory condition. Tjitrosoedirdjo et al. (1999) reported that the potency of weevil reproduction could reach about $50 \%$.

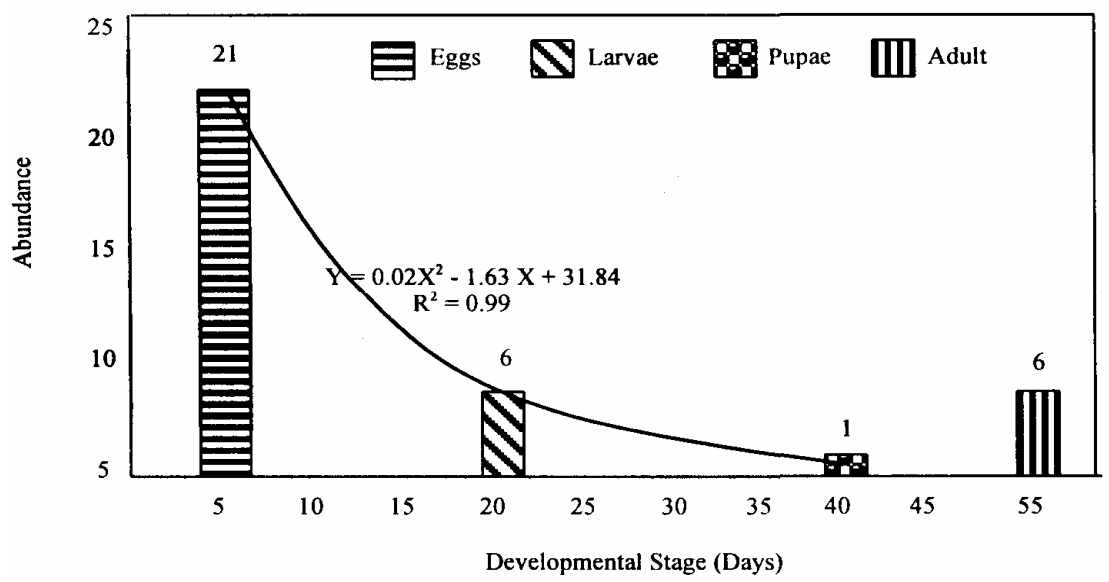

Figure 3. Structure of developmental stages ofNeochetina spp. at Situ Bagendit lake.

The difference between potential survival rate of the weevils in the laboratory and the fact in the field may be attributed to various limiting factors resulting in low survival rate. It was suspected that some predaceous fish could cause the low survival rate of the weevils in the Situ Bagendit lake. An experiment was then set up to proof the possible attack from predaceous fish. The results are presented in Table 1.

Table 1. Average number of pupal and adults stages of water hyacinth weevils and damage severity under simulation to test the role of predators in inhibiting the population increase

\begin{tabular}{lccc}
\hline \multicolumn{1}{c}{ Treatment } & Number of pupae & Number of adults & $\begin{array}{c}\text { Damage Severity } \\
(\%)\end{array}$ \\
\hline & & 2 months after infestation \\
Without screen net on the base & 9 & 6 & 3.0 \\
With screen net on the base & 10 & 8 & 3.1 \\
& & 3.5 months after infestation & \\
Without screen net on the base & 22 & 49 & 42.9 \\
With screen net on the base & 26 & 56 & 50.0 \\
\hline
\end{tabular}

Note : The figures were the average of 5 replications 
Table 1 indicates that the number of both pupae and adult weevils under screen cages equipped with screen net on its base after two and three and a half months were higher than the cages without screen net on the base. The cages which were equipped with screen net prevented from possible predation of the weevils. Unpublished data collected from a simulation experiment showed that various fish may consume root-bearing pupae under laboratory conditions. There were various fish such as common carp (Cyprinus carpio), tilapia, Oreochromis mosambicus, cat fish, found in Situ Bagendit lake. Spiders were reported to predate and prey on TV. bruchi larvae (Tjitrosoedirdjo 1998). At Situ Bagendit lake, spiders were often found, so they might be one of the natural enemies of water hyacinth weevils.

The slow population increase of the weevils at the release site may lead to a conclusion that Neochetina spp. are not effective control agents. It was reported that effectiveness of an biotic control agent may be affected by various factors such as by climate (Jayanth and Visalakshy 1990; Grodowitz et.al. 1991).

Although the population increase in Situ Bagendit lake was very low, the increasing trend during the observation period confirmed that Neochetina weevils have established in the lake. Therefore, additional releases of same biological control agents are not necessary.

\section{Relationship between the attacks of water hyacinth weevils and fungus}

A plant pathogenic fungus may disperse from an initial point of infection to other host plants through a direct contact with the infected parts. Aside of that, spores and mycelia may be transferred to other host plants by carrying agents. An adult weevil of Neochetina may act as a carrying agent of the spores and mycelia of the fungus, A. eichhorniae. A monthly interval observation carried out to assess the damage severity of water hyacinth plants by each biological control agent in Situ Bagendit lake is presented in Table 2.

It was obvious that there was no interaction between the attack of adult weevils and the fungus. Data obtained from laboratory experiment showed that a higher damage severity of water hyacinth due to both biotic control agents caused a more serious damage (Kasno et al. 1998). Probably the level of both weevil populations and the fungus colony were not high enough to cause such speculated effect.

According to Kasno et al. (1998) various fish such as tilapia and common carp at the feeding test showed that those fish predated on pupae which were in the roots of water hyacinth. Aside from fish, frogs and eel fish might also attack the weevils. Under the simulated experiment, the weevil's elytra were found in the crop of the frog.

At Situ Bagendit lake, spiders were often found, so they might be the natural enemies of the weevils. According to Tjitrosoedirdjo (1998) spiders were able to catch and prey on $N$. bruchi larvae. 
Correlation between the damage severity of water hyacinth due to the weevils and fungus

The percentage of weevil attack and the number of feeding scars on the second youngest leaf of water hyacinth is shown in Table 2 and Appendix 1. The attack level of the pathogenic fungi $A$. eichhorniae and the weevil Neochetina spp. at Situ Bagendit lake did not show significant correlation in causing damage to water hyacinth, because the attack was relatively low.

Table 2. Correlation between damage severity of water hyacinth plants due to the attacks of weevils and

\begin{tabular}{lccc}
\hline Month & Fungal attack (\%) & Weevil attack (\%) & $\begin{array}{c}\text { Number of spot at the second } \\
\text { youngest leaf }\end{array}$ \\
\hline June & $36.5 \mathrm{~b}$ & $35.0 \mathrm{~b}$ & $299 \mathrm{c}$ \\
July & $32.7 \mathrm{~b}$ & $22.7 \mathrm{~cd}$ & $275 \mathrm{c}$ \\
August & $40.5 \mathrm{~b}$ & $17.5 \mathrm{~d}$ & $280 \mathrm{c}$ \\
September & $36.5 \mathrm{~b}$ & $31.0 \mathrm{bc}$ & $202 \mathrm{c}$ \\
October & $48.0 \mathrm{a}$ & $22.0 \mathrm{~cd}$ & $221 \mathrm{c}$ \\
November & $37.0 \mathrm{~b}$ & $29.0 \mathrm{bc}$ & $268 \mathrm{c}$ \\
December & $38.4 \mathrm{~b}$ & $34.0 \mathrm{~b}$ & $313 \mathrm{c}$ \\
January & $35.0 \mathrm{~b}$ & $34.0 \mathrm{~b}$ & $620 \mathrm{~b}$ \\
February & $37.0 \mathrm{~b}$ & $70.0 \mathrm{a}$ & $874 \mathrm{a}$ \\
\hline
\end{tabular}

Note: Figures followed by the same letter in the same column are not significantly different according to Duncan Multiple Range Test at 95\% confidence level.

\section{CONCLUSIONS}

In the spatial distribution, adult of water hyacinth weevils actively dispersed in all cardinal directions following the presence of water hyacinth. The distribution pattern of the adults of water hyacinth weevils was initially contagious or clumped, but later on they tended to spread uniformly. Neochetina. bruchi and $N$. eichhorniae released at Situ Bagendit lake since 1996 have become widely established. The survival rate of water hyacinth weevils at Situ Bagendit lake being estimated by the age structure showed a much lower rate than its reproduction potential found in the laboratory. The damage severity of water hyacinth plants due to A. eichhorniae and Neochetina spp. at Situ Bagendit lake was not significantly correlated. 
BIOTROPIA NO. 17, 2001

\section{REFERENCES}

Bashir, M.O. 1984. The establishment and distribution of natural enemies of waterhyacinth released in Sudan, Short communication. Tropical Pest Management 30(3):320-323.

Caunter, I.G. and S. Mohamed. 1992. Effect ofNeochetina eichhorniae on waterhyacinth in Malaysia and its interaction with Myrothecium roridum. In: Proc. of the $3^{\text {rd }}$ International Conference on Plant Protection in the Tropics (eds. P.A.C. Ooi. G.S. Lim and P.S. Teng) 6:261-264. MAPPS, Kuala Lumpur, Malaysia.

Center, T.D., Steward, K.K., and M.C. Bruner. 1982. Control of waterhyacinth (Eichhorniae crassipes) with Neochetina eichhorniae (Coleoptera:Curculionidae) and a growth retardant. Weed Science 30(5):453-457.

Center, T.D. and A.D. Wright. 1991. Age and phytochemical composition of water hyacinth (Pontederiaceae) leaves determine their acceptability to Neochetina eichhorniae (Coleoptera: Curculionidae). J. Environ. Entomol. 20(l):323-334.

Charudattan, R. 1986. Integrated control of waterhyacinth (Eichhorniae crassipes) with a pathogen, insects, and herbicides. Weed Science 34 (Suppl.) 1):26-30.

Donnelly, G. 1997. Mass rearing insects for biological control of weeds. In Biological control of weeds: theory and practical application. M. Julien and G. White (eds). ACIAR Monograph No 49. Canberra: 89-96

Galbraith, J.C. 1987. The pathogenicity of an Australian isolate of Acremonium zonatum to waterhyacinth, and its relationship with the biological control agent, Neochetina eichhorniae. Australian Journal of Agricultural Research 38:219-229.

Goyer, R.A. and J.D. Stark. 1984. The impact of Neochetina eichhorniae on waterhyacinth in Southern Louisiana. Journal of Aquatic Plant Management 22:57-61.

Grodowitz, M.J., R.M. Steward and A.F. Confrancesco. 1991. Population dynamics of waterhyacinth and the biological control agent Neochetina eichhorniae (Coleoptera: Curculionidae) at a Southern Texas location. Environmental Entomology 20(2):652-660.

Harley, K.L.S. 1990. The role of biological control in the management of water hyacinth, Eichhornia crassipes. Biocontrol News and Information 11(1): 11-22

Jayanth, K.P. 1988. Successful biological control of waterhyacinth (Eichhorniae crassipes) by Neochetina eichhorniae (Coleoptera: Curculionidae) in Bangalore, India. Tropical Pest Management. 34(3):262266.

Jayanth, K.P. and P.N.G. Visalakshy. 1990. Studies on drought tolerance in water hyacinth weevils Neochetina eichhorniae and N. bruchi (Coleoptera: Curculionidae). J. Biological Control 4(2): 116119.

Julien, M.H and W.W. Griffith. 1998. Biological control of weeds: A world catalogue of agents and their target weeds. $4^{\text {th }}$ ed. CABI, UK. 223p.

Julien, M., W.W. Griffith and A.D. Wright. 1999. Biological control of water hyacinth. ACIAR Monograph No.60. Canberra. 87p.

Kasno, Okky S. Dharmaputra, Sunjaya, A.S.R. Putri and H.S. Handayani. 1998. Establishment of water hyacinth weevil, Neochetina bruchi. SEAMED BIOTROP. 26p. 
Saraswati, R. 1980. The possible use of the combination Neochetina eichhorniae Warner - Myrothecium roridum Tode ex Fr. to control waterhyacinth (Kemungkinan penggunaan kombinasi kumbang moncong Neochetina eichhorniae Wamer dan jamur penyakit Myrothecium roridum Tode ex Fr. untuk pengendalian eceng gondok Eichhornia crassipes (Mart.) Solms. Faculty of Mathematic and Natural Science, Padjajaran University, Bandung. 44 p.

Tjitrosoedirdjo, S.S. 1998. Biological control of water hyacinth, water fern and giant mimosa using insect natural enemies (Pengendalian hayati eceng gondok, kiambang dan klampis air dengan menggunakan serangga musuh alami.) Research Report of Competitive Grant of Higher Education, II/5. Directorate General of Higher Education. Department of Education and Culture.

Wright, A.D. 1979. Preliminary report on damage to Eichhornia crassipes by an introduced weevil at a central Queensland liberation site. Proceeding of the seventh conference of the Asian Pasific Weed Science Society, p: 227-229. 
BIOTROPIA NO. 17, 2001

Appendix 1. Analysis of variance on the percentage of damage severity due to weevils and fungi, and the number of spots at the second youngest leaves of water hyacinth at Situ Bagendit, Garut regency

\begin{tabular}{lcccccc}
\hline \multirow{2}{*}{ Source } & Fungal infection (\%) & Weevil infestation (\%) & $\begin{array}{c}\text { Number of spots at the second } \\
\text { youngest leaves }\end{array}$ \\
\cline { 2 - 7 } & Df & F-value & Df & F-value & Df & F-value \\
\hline Treatment & 8 & $2.9^{* *}$ & 8 & $21.6^{* *}$ & 8 & $37.9^{* *}$ \\
Error & 81 & & 81 & & 81 & \\
\hline
\end{tabular}

Df $=$ degree of freedom; $* *$ = significant at $99 \%$ 